\title{
The Inevitability of Shadowy Banking
}

\author{
Edward J. Kane \\ Boston College \\ Presented at the Federal Reserve Bank of Atlanta \\ 2012 Financial Markets Conference \\ Financial Reform: The Devil's In the Details \\ Atlanta, Georgia \\ April 10, 2012
}




\section{THE INEVITABILITY OF SHADOWY BANKING*}

Edward J. Kane

Boston College

If you pick up a starving dog and make him prosperous, he will not bite you; that is the principal difference between a dog and a denizen of Wall Street.(with apologies to Mark Twain)

\section{What is Shadowy Banking?}

Paul McCulley and Gary Gorton have used the idea of banking in dark places as a clever way to clarify and extend the meaning of the even more puzzling term "nonbank bank." A shadow bank is an institution or bank-sponsored special-purpose vehicle that has persuaded its customers that its liabilities can be redeemed de facto at par without delay (or can be traded as if they will be executed at par without fail at maturity) even though they are not formally protected by government guarantees. My title adds a " $y$ " and an "ing” to their term to stretch the shadows to include not just firms like money-market funds and government-sponsored enterprises, but instruments such as swaps, repurchase agreements and AAA securitizations that may trade for substantial periods of time as if they carried zero counterparty risk.

Of course, any instrument can trade this way if it is believed that authorities will be afraid not to absorb all or most of the losses its holders might suffer. The perception of a governmental "rescue reflex" is a key element of shadowy banking. It permits aggressive banks to back risky positions with the ex ante value of its contingent safety-net support ( i.e., safety-net capital extracted from hapless taxpayers) rather than stockholder equity.

"Shadowy" is meant to encompass any effort to play upon this reflex to extract implicit (i.e., confidently conjectured) guarantees from a nation's financial safety net without informing taxpayers about their exposure to loss and without adequately compensating them for the value of the contingent credit support that authorities' rescue reflex imbeds in the shadowy entity's contracting structure. Although macroeconomists stubbornly portray the taxpayer side of such claims as an externality, it is more accurately a central part of the industry's implicit contract for regulatory services: a market-completing "taxpayer put" which the industry understands as a government-enforced obligation for taxpayers to rescue large and politically powerful firms when they are in difficult straits.

In the words of the late James Q. Wilson (1980), the federal bureaucracy operates "not in an arena of competing interests to which all affected parties have reasonable access, but in $a$ shadowy world of powerful lobbyists, high-priced attorneys, and manipulative 'experts'” (my

\footnotetext{
* The author is grateful to Richard Aspinwall, Rex DuPont, Stephen Kane, James Thomson, Larry Wall and especially Robert Dickler for helpful comments on an earlier outline.
} 
italics). Lobbyists for protected firms work hard to convince politicians and regulators that providing contingent support to important financial enterprises is in officials' best interests if not necessarily those of society as a whole.

Shadowy banking might better be called Safety-Net Arbitrage. It covers any financial organization, product, or transaction strategy that --now or in the future-- can opaquely (i.e.,nontransparently) extract subsidized guarantees from national and cross-country safety net by means of "regulation-induced innovation." This way of thinking about the safety net clarifies that taxpayers serve as its buttresses. It also implies that the shadowy sector is a moving target. It consists of whatever entities can issue a worrisomely large volume of financial instruments that, given the boundaries of current laws or control procedures, are either actually or potentially outside the firm grip of the several agencies currently charged with monitoring and managing the financial safety net.

\section{Shadowy Banking is Shaped by a Regulatory Dialectic}

"Dialectics" is the art of arriving at the truth by becoming aware of contradictions in opposing beliefs and overcoming or lessening the contradictions with logical analysis or empirical evidence. The Hegelian Dialectical Model seeks to explain institutional change as a process of Conflict Generation, Conflict Resolution, and Conflict Renewal. The process has three stages: Thesis-Antithesis-Synthesis. The predictive power of this evolutionary model comes from positing that each synthesis serves as a thesis to be challenged afresh by new ideas and experience.

Regulation generates conflict because it seeks to impose outside rules on another party's behavior. To the extent that they limit one's freedom of action, outside rules impose an unwelcome burden on an intended "regulatee." This is why changes in Regulation beget Avoidance behavior (i.e., inventive ways of getting around the new rules) and, by renewing the conflict, Avoidance begets Regulatory Change. As in any dialectical process, the interaction of the conflicting forces supports a process of endless action and reaction. Viewed as a game, as the alternating sequences of moves impose, escape, and adjust regulatory burdens, they simultaneously remold financial institutions, contracting protocols, and markets around the world.

An Instructive Analogy. Most of us have our first encounter with regulation within our immediate family where we emerge as an inexperienced child regulatee. Our parents set rules and proffer rewards and punishments in hopes of conditioning us to behave according to these rules. Short-term rewards usually take the form of tangible and intangible expressions of approval, while short-term punishments run a gamut of physical and psychological sanctions.

The long-run goal is to develop a well-behaved child who takes pride in living up to the set of parental rules, which is to say a child who has developed a keen sense of shame. When conformance with parental rules becomes a child's own preferred course of behavior (and ideally a source of self-esteem), enforcement problems melt away. But most parents show a rescue reflex of their own, so that conditioning efforts at least partially backfire. Children who 
recognize this reflex and refuse to be bound by parental rules may pursue either of two paths: defiant disobedience or creative avoidance. For a given rule, the mixture of compliance, avoidance, and evasion that is chosen depends on the strength of the child's aversion to the mandated behavior (compliance costs) and on the relative opportunity costs of evasion and avoidance.

Autonomous children that psychologists would label as well-adjusted generate most of their long-run regulatory environment on their own. They fashion their particular ideas of right and wrong and pursue strategies of prudent circumvention that are designed to reconcile their wants and needs with the outer limits of parental rules. Like banks, securities, and insurance firms, they learn to comply with the letter of unwelcome rules while shamelessly abusing their spirit. By learning to find and exploit loopholes, a child relieves himself or herself simultaneously of guilt and unpleasant restraints. Moreover, the sense of having overcome adversity in an inventive way tends to instill and sustain a positive view of one's own cleverness.

Avoidance differs from outright evasion by respecting the words of a command, even as the intent of the command is at least partially frustrated. The avoider has a lawyerlike or playful perspective on rules that differs from the criminal mindset of the nonupright, undisciplinable child. An evader is unruly. An avoider is a resourceful escape artist who welcomes the challenge of shaking free from externally imposed restraints.

Loopholes as Entitlements. It is costly for regulators to come to grips with avoidance behavior. Parents and government officials are reluctant to search for and eliminate loopholes in advance or to close loopholes until they have taken time to appreciate their effects. However, unlike government regulators in representative democracies, parents are free to discourage circumvention by punishing avoidance ex post as if it were the same as evasion. Children can lobby, but they cannot vote into office a more desirable set of parents. Moreover, because children's regulatory rights are not closely protected by an administrative system of appellate law, the opportunity cost of avoidance behavior is high for children whose parents refuse to acknowledge and honor the legitimacy of searching out loopholes in their rules.

This discussion is designed to clarify that darkness can flood a space every bit as much as light can. Processes of financial regulation and financial-institution avoidance produce darkness and light at the same time. Rules and loopholes are written simultaneously into the text of every statute and administrative rule. In far too many cases, the loopholes are seen as entitlements that were chiseled into the rules by skilled and knowledgeable lobbyists who frame problems and potential solutions in a self-interested way. As we watch regulators trying to propose and finalize the hundreds of rules required by the Dodd-Frank Act of 2010 (DFA) for the avowed purpose of lessening subsidies to aggressive risk-taking, we must understand that Congress and the industry were well aware that regulatory personnel would ultimately want to lighten the rulemaking and enforcement burdens that the DFA would place on them.

The main difference between each new rule and the loopholes it contains lies in the relative ease with which their entailments and purposes may be understood by the public. Rules 
are phrased in plain language and set in large print. Loopholes are imbedded in exotic codes and written in hard-to-see fine print.

The Regulatory Dialectic is an evolving game that has no stationary equilibrium (Kane, 1981, 1983). It is played repeatedly by differently informed, differently incentivized, and differently skilled players: financiers, regulators, lobbyists, politicians, customers, credit-rating firms, and taxpayers. The timing and space of potential moves cannot be fully known in advance, but individual moves are of three basic types: (1) Adjustments in Regulation; (2) Burden-Softening Lobbying, Disinformation, and Avoidance (which occur rapidly and creatively); and (3) Reregulation (which usually takes considerable time to develop). Some of the players (taxpayers and some regulators) are perennial "suckers," who only occasionally and temporarily realize that the game is rigged against them.

\section{Three Different Categories of Shadowy Firms and Practices}

Safety-net arbitrage is a form of circumventive behavior. It seeks to identify and exploit gaps in a nation's or region's framework of financial regulation and supervision that allow the arbitrageur to extract safety-net benefits without paying their full cost of production. It is a dynamic and creative form of purposively self-interested behavior. Inevitable differences in the information available to institutions, regulators, and taxpayers mean that, whatever changes in the fabric of regulation financial authorities make, they will always be playing from behind. This is why shadowy banking and the bubbles and crises it generates and feeds upon can never be eliminated. The damage crises create can, however, be mitigated by throwing more light on the process of regulatory arbitrage.

Three distinct kinds of regulatory arbitrage take place within the shadowy sector. Shadowy Banking includes firms with financial products or charters that:

1) Do not fall under the rubric of existing laws (i.e., exploit statutory gaps);

2) Are deliberately designed to fall outside the span of control defined by existing regulatory practices (i.e., exploit procedural gaps);

3) Can be redesigned to exploit either or both types of gaps once the benefits of escaping burdensome regulations or oversight become great enough to overcome implementation costs (i.e., will take advantage of gaps that have not yet been exploited).

It is useful to cite some examples. Large US institutions can derive benefits from statutory or procedural gaps by using subsidiaries to perform activities in foreign countries that are outlawed or more closely regulated here. Any bank can even more easily circumvent the FDIC's statutory limits on account coverage by joining the Promontory International Network, whose founders include (ironically) a former Comptroller of the Currency and a former Governor of the Federal Reserve System. This firm offers a product that allows a single depositor to up its FDIC coverage to as much as $\$ 50$ million. Promontory named this product the "Certificate of Deposit Account Registry Service" (CDARS). CDARS acts as a clearinghouse. It re-books balances in excess of FDIC limits (i.e., statutorily uninsured deposits) 
from one institution as below-the-limit increments in deposits that are swapped into other institutions. The injustice of the arbitrage is that Promontory collects fees for re-booking these deposits, while the FDIC incurs the costs of providing the over-line coverage. It would be interesting to see some statistics on the extent of CDARS-supplied deposits that have turned up in failed and problem banks. CDARS shows that swaps designed to arbitrage the safety net can easily go viral if authorities do not intervene. At last report, over 3,000 financial institutions belonged to the CDARS deposit-swapping network. Like sponsors of the first retail moneymarket funds (one of which had the brass to adopt the acronym FDIT), the sponsors of CDARS arbitraged the safety net and dared authorities to do anything about it.

The lessons I take from the CDARS program are that almost anything that carries an explicit or implicit government guarantee can be swapped in great volume and that high volume establishes the equivalent of a squatters right because authorities are reluctant to roll back innovations once they have achieved widespread use.

\section{Why Does Shadowy Banking Endure?}

The longer I live the better I understand Friedrich Nietzsche's assertion that "There are no facts, only interpretations." Almost all forms of shadowy banking offer some benefits to society. This is because at the same time that financiers use emerging technologies to extract safety-net subsidies, they create new, better, or cheaper services for their customers. This favorable dimension of innovation is routinely overstressed in the narratives that sponsors of shadowy instruments offer the public to justify their existence. See, for example, the pleas to spare money-market funds (MMFs) from further restrictions that former Comptroller Hawke (e.g., 2012a and b) has published on the American Banker's Bank Think website this year. Hawke takes issue with the idea that MMFs deserve to be called shadow banks because they are in fact supervised by the SEC. He denies that MMFs face an "appreciable threat of future runs" (assuming away the danger of concentration risk) and frames his presentation to suggest that the temporary liquidity facilities put in place in September 2008 did not cost a "single penny of public money."

Regulatory arbitrage can provide safety-net benefits for particular firms, politicians, regulators, and categories of customers. The various statutory and procedural gaps offer legal, but inherently unethical opportunities for different parties to exploit and corrupt one another. Corruption deepens as the stakes rise and when incentive conflict tempts other players to join in a coalition to exploit taxpayers. As Francis Bacon explains, opportunity makes the thief.

Central banks' rescue reflex leaves taxpayers holding the short side of an implicit regulatory contract that allows elite financial firms to put ruinous losses to government safety nets if and when creditors refuse to roll over their debts and derivatives at "reasonable" (i.e., low) cost. That exploiting taxpayers through the safety net is touted as evidence of managerial proficiency without also being worn as a badge of shame signals the extent of the moral vacuum that has overtaken the debate over bailout policies. 
Genuine reform has to flow from the common-sense recognition that other players owe moral duties to taxpayers whom current policy has converted into disadvantaged de facto equity investors in protected firms. Kane (2012) offers two justifications for requiring protected firms to measure and report honestly and frequently on the evolving value of taxpayers' stake in socalled too-big-to-fail enterprises. The first is a legal argument: the idea that, because they are de facto equity investors, corporate law should accord taxpayers the same informational and fiduciary rights to prudent stewardship that the law gives to explicit shareholders. In German, the phrase for violating a fiduciary duty can be translated as "acting despite better knowledge and conscience." The second is a moral argument based on Kant's Second Imperative. Kant's second imperative maintains that exploitation of others is intrinsically wrong. Kant argues that one may not rightfully use other parties - as many a financier has-- only as means to benefit oneself.

\section{How Incentive Conflict Expands Systemic Risk and the Financial Safety $\mathrm{Net}^{1}$}

To the extent that technological change seeks to exploit a country's safety net in hard-toobserve ways and is protected by regulatory lags and regulatory capture, it leads to excessive risk-taking and sows the seeds of future financial crisis.

Empirical research I have conducted with various colleagues (e.g., Carbo, Kane, and Rodriguez, 2008, 2011a, and 2011b) supports the hypothesis that Systemic Risk can be measured by the value of an individual firm's contribution to the financial sector's aggregate "taxpayer put.” The value of a protected firm's side of the put increases both with the volatility of its asset holdings and with the fragility of its funding structure. By reinforcing authorities' rescue reflex, a firm can further disadvantage taxpayers by building up its political clout, size, and complexity. These latter attributes enhance management's ability to delay regulatory punishments and to use the resulting period of grace to neutralize regulatory restraints and to trigger more firmly the rescue reflex.

Basel Accords seek to limit safety-net subsidies by setting boundaries on the extent to which regulated institutions can leverage their balance sheets. The plan is to keep losses from spilling beyond a firm's internal capacity to bear losses by aligning its ownership capital with its exposure to economic loss.

The linchpin of the Basel system is to measure loss exposure by the sum of risk-weighted assets (RWA). The weights employed in the first two accords were fixed at arbitrary levels and give a bank virtually no credit for the extent to which it might have diversified or hedged the risks in its loan portfolio. Nor did the formulas make much effort to account for operational or interest-rate risk. Finally, although Basel II authorized tying some weights to credit ratings, none of the accords has linked the system of risk weights it applies to a benchmark set of assets or to movements in the average or marginal risk premiums that one could observe in loan markets.

These disconnects artificially distort patterns of bank risk transfer by creating opportunities for clever banks to capture safety-net subsidies by arbitraging the weighting

\footnotetext{
${ }^{1}$ This discussion draws explicitly on Kane $(2007,2012)$.
} 
system. The first principal loophole came from large institutions' success in corruptly persuading Credit Rating Organizations (CROs) to help them to game the Basel system by overrating shadowy packages of securitized loans. (This is and ISDA's determination to keep credit default swaps on Greece from paying off as the price of its debt declined exemplify how shadowy institutions tend to corrupt one another). A second avenue of avoidance was, that when regulatory demands for capital first begin to generate a compliance burden at a particular bank, its managers found it temptingly easy to appear to recapitalize by manipulating its loan-loss reserves and by selling or securitizing a sufficient amount of its least-risky assets.

Regulators did not seem very worried about the size and perversity of various accounting, securitization, swap, and loan-sales loopholes. Even after the crisis ensued, practical people more or less turned a blind eye toward the loopholes in the Basel system. The fact that even during the crisis most banks continued to post a capital position far in excess of Basel standards suggest that the minimum standards were not particularly burdensome. Despite efforts by U.S. and foreign banks and regulators to increase the granularity of the risk categories by which capital standards were set in previous years, risk-weighted capital proved of no help in predicting what banks would and would not need to be rescued (Demirgüç-Kunt, Detragiache, and Merrouche, 2011).

In the forum in which Basel III and its successors are being crafted today (the Basel Committee on Banking Supervision, BCBS), reform plans continue to mischaracterize capital and misweight risk Although they should know better, negotiators act as if it is okay to temper the fiduciary duties that this paper associates with monitoring the size of a bank's taxpayer put. They content themselves with aligning a banking organization's accounting leverage with politically distorted conceptions of its exposure to risk. Regulators seek only to force protected institutions to accept a marked increase in their equilibrium ratio of accounting net worth to total assets. But leeway inherent in reporting loan-loss reserves and other discretionary items makes accounting net worth a shadowy concept whose value does not reliably reflect an institution's ability to absorb losses generated by its appetite for risk. In practice, a firm whose books make a show of high capital is often more risky than a firm whose books show less (Koehn and Santomero, 1980; Diamond and Rajan, 2000).

Hence, the preventive leg of the Basel policy prognosis is overly hopeful and not supported by empirical research. Financial crises are a fact of life. Where data exist, they show that every country's financial sector passes through a succession of three-stage sequences: a precrisis bubble in credit, an actual crisis, and a post-crisis period of creative destruction and healthy recovery (Kindleberger, 1978; Reinhart and Rogoff, 2009). Of course, the durations of the different stages vary across countries and across time, and transitions from one stage to another become clear only in retrospect.

But bubbles and crises can be amplified by weaknesses in insolvency detection and by subsidies to risk generated by zombie firms' ability to battle for bailouts. The Regulatory Dialectic indicates that crises and subsidies are generated in large part by path-dependent collisions of (1) efforts by regulators in their supervisory capacity to control leverage and other 
forms of risk-taking with (2) disruptive efforts by regulated and "shadowy" financial institutions to expand risks in nontransparent ways and to shift responsibility for ruinous outcomes onto national safety nets.

In the presence of a safety net, bank managers face a threefold incentive: to lobby for lenient standards, to hide and understate risk exposures, and to overstate accounting net worth. This set of incentives makes risk and stockholder-contributed net worth hard to measure accurately and reliable standards by which to judge improvements in incentive alignment difficult to set and enforce.

Undone by the Regulatory Dialectic. Because regulators have relatively short terms in office, they are attracted to temporary, rather than lasting fixes. The costs and benefits of capital requirements extend far into the future and are by no means fixed or exogenous. Regulatees search tirelessly for ways to reduce the burdens of regulation. Value maximization leads bankers to devise progressively lower-cost ways to exercise political clout, to adjust and misreport their asset and funding structures, and to choose the jurisdictions in which they book particular pieces of business.

This kind of financial engineering resembles what happens on a "makeover" television show. Top managers deploy the equivalents of fashionistas, cosmeticians, and hairdressers to revamp their firm's external appearance without changing the underlying character of the risk exposures that they expect taxpayers to support.

The endogeneity of regulatory burdens should lead one to view: (1) ongoing negotiations in the Basel Committee on Banking Supervision that seek to establish global risk-based capital rules and (2) disruptive bank objections to -and circumvention of-emerging rules as conflicting forces in a dialectical evolutionary process that can be modeled as a rigged game. ${ }^{2}$

Weaknesses in the way US and EU regulators chose to implement Basel standards create differences in the costs of loophole mining that help to explain why the crisis hit their financial systems harder than those of Canada, Asia, Latin America, and Oceania [see Shadow Financial Committee Report(2011), posted at aei.org]. Although Basel II tied risk weights for sovereign debt to credit ratings, it permits national authorities to go below those weights for centralgovernment debt (or debt guaranteed by a central government) that is issued and funded in the currency of the country in question. For political reasons, US regulators assigned unrealistically low weights to mortgage-backed securities and EU officials set zero risk weights for memberstate debt. The European Central Bank (ECB) contributed to the process by accepting the sovereign debt of all Eurozone countries at par value when posted as collateral for ECB loans. When and as the debt of the "GIPSI" nations of Greece, Ireland, Portugal, Spain and Italy began in that order to be downgraded, the EU and the ECB failed to "haircut" their treatment of these countries' increasingly risky debt.

All this was part of a larger strategy of cross-country denial and concealment of financialsector risk exposure. EU stress tests and Basel's risk-weighted capital ratios (Demirgüç,-Kunt, Detragiache, and Merrouche, 2011) failed demonstrably to distinguish between failing and viable

\footnotetext{
${ }^{2}$ Although this model can be formalized, only a narrative form is presented here.
} 
banks. The fundamental weakness in Basel arrangements is their contractual incompleteness. Basel accords fail to make credit-rating organizations and individual-country regulators accountable either to the Basel Committee as a whole or to banking regulators in other member countries.

The Hegelian perspective dramatizes the incentive conflicts that regulators and regulatees face. Crises and subsidies arise in a path-dependent manner from prior tensions between efforts by regulators in their supervisory capacity to control leverage and other forms of risk-taking and efforts by regulated and "shadowy" financial institutions to expand risks in nontransparent ways and to shift responsibility for ruinous outcomes onto national safety nets.

Loopholes make lobbyists’ disinformational claim that tougher capital requirements will make banks pass up profitable, but socially risky financial opportunities seem distressingly dishonest. The Occupy movement suggests that the crisis is at least temporarily teaching the public the following lessons about the game regulators and regulates have been playing on them: Accounting ratios are not difficult to overstate and financial firms do not accept high statutory burdens passively. Other things equal, higher capital requirements lead banks to choose riskier strategies and, both individually and collectively, to conceal the resulting loss exposures from regulators so as to minimize adverse effects on bank profits and stock prices.

\section{Why Basel III and the Dodd-Frank Act Cannot Promise to Give Much Better Results}

The Basel Approach has Two Fundamental Weaknesses: (1) accounting ratios are easy to manipulate and risks are easy to hide and/or to misrepresent and (2) authorities are willing to exaggerate the "comfort" taxpayers should take from loan-loss reserves, credit-rating firms, liquidity swaps, and light-touch stress tests. The root problem is that financial institutions routinely aim at the mere appearance of regulatory compliance. Managers act as if they are playing an amusing game of hide and seek. They feel morally justified in hiding risks from regulators and denying repeatedly the existence and extent of safety-net subsidies.

The Dodd-Frank Act purports to address the causes of the financial crisis. But like Basel III, the DFA fails to rectify incentive distortions in the web of safety-net supervision and addresses narrower issues in ways that intensify rather than dispel the uncertainty and lack of trust that bedeviled wholesale financial markets in the first place.

The DFA assigned the task of installing the most controversial features of Dodd-Frank as homework to various regulatory agencies. More than 18 months later, unsettled issues include: risk retention in securitization; capital surcharges for systematically important financial institutions (SIFIs); new restrictions on credit rating organizations; derivatives trading rules; limitations on proprietary trading; and restrictions on compensation, dividends, and stock buybacks. How authorities will finally resolve these issues remains exposed to further rounds of shadowy lobbying pressures and the resulting delays in implementation accommodate low-cost safety-net abuse in the interim. 


\section{Reinterpreting The Role of Swaps in the Panic of 2008}

It has become customary to characterize the bankruptcy of Lehman Brothers as triggering the panic of September 2008. However, I believe that public confidence in the competence and fairness of the government's regulatory leadership and the reliability of private performance guarantees was destroyed by the combination of a yet to-be fully explained double U-turn in bailout policy (of which Lehman was only the smallest part) and subsequent Presidential fearmongering in support of a panicky blank-check program known as TARP (Kane, 2009). Within the space of a few weeks, federal officials moved from contributing over $\$ 100$ billion to creditors of Fannie and Freddie, to making the creditors of Lehman take their lumps in bankruptcy, then to committing roughly $\$ 180$ billion to bailing out the creditors and swap counterparties of the American International Group (AIG) and demanding that Congress appropriate $\$ 700$ billion to buy up distressed assets at inflated prices. The AIG rescue broke new ground because it represented the first time that government support for the defaulting obligations of an insolvent US insurance firm had simultaneously disavowed the importance of creditor haircuts and exceeded the value of state guaranty schemes.

Two things made AIG different from other insurance insolvencies. First, at the time of its implosion it had $\$ 1.06$ trillion in assets. This made it by far the largest "insurance firm" in the country. Second, although AIG's traditional life, casualty, and retirement business was supervised by state officials in traditional ways, various "insurance-related activities" had morphed out of the jurisdiction of state regulatory regimes via swap contracts. These activities were conducted in opaque subsidiary corporations that transacted in convenient foreign jurisdictions with a large number of foreign counterparties. To clarify the regulatory arbitrage this entails, consider the advantages of using a swap to guarantee payments due on a bond. In the US, a bond insurance contract would have had to be written by a state-regulated entity. This underwriter would explicitly have to estimate and reserve for the loss exposures generated by its guarantee, establish the existence of an insurable interest on the part of the counterparty (i.e., a long position in the bond), and counterparty claims would be settled over time by assuming the string of future payments specified by the bond contract. Although Dodd-Frank rulemaking might change this, credit default swaps dispensed with these restrictions. Over-the-counter CDS market makers like AIG could write contracts with counterparties that had no insurable interest, did not have to document how they reserved for losses, and at settlement would usually be required to make a single lump-sum payment.

The highly concentrated risks AIG took in swap and securities-lending activities would have been hard for state commissioners to reconcile with their traditional concern for protecting policyholder interests had they thought themselves responsible for overseeing them. State officials took some comfort from the fact that AIG subsidiaries and the firm as a whole were supervised at the federal level as a thrift-institution holding company by the Office of Thrift Supervision (OTS). Unfortunately, AIG management knew all too well that this regulator lacked the expertise, the windows into foreign jurisdictions, and the incentives to monitor and control the leverage and volatility inherent in AIG's, burgeoning derivatives and securities-lending 
businesses. A useful way to understand the AIG debacle is to think of one of its divisions as a "booking bureau" whose task was to place derivatives business in shadowy subsidiaries and markets which left its potential regulators most overmatched.

AIG illustrates the maxim that firms - like people — are born simple, but die of complications. Corporate complications are both structural and contractual. Table 1, which is taken from Sjostrum (2009), shows how AIG partitioned its activities and that the profitability of AIG's financial-services subsidiaries declined steeply in 2007 and 2008. These losses triggered cash flows and collateral calls in credit default swaps (CDS) and securities lending that AIG proved unable to sustain.

One alleged benefit of segregating different product lines within a holding-company structure is to erect constructive firewalls intended to stop losses in one unit from spreading to other units of the firm. Another is that this arrangement can facilitate the restructuring of the firm if and when it falls into distress. However, neither of these benefits was realized in the AIG debacle. Because top management decisions had not been closely monitored, AIG officials were tempted to use cross-guarantees from the traditional insurance units to lessen the collateral requirements imposed or increase the fees collected on other subsidiaries' deals with swap and securities-lending counterparties. In the absence of interaffiliate guarantees and in states where such guarantees might prove unenforceable, the profits of the insurance units would have stayed positive because counterparties could not have reliably forced the parent to honor claims written against loss-making affiliates. At least arguably, the doctrine of corporate separateness would have allowed the claims of derivatives counterparties to be separated from the insurance units in a prepackaged bankruptcy and given appropriate haircuts.

Both at the Treasury and the Fed, the initial justification for rescuing AIG and keeping its many counterparties whole was not protecting the firm's policyholder and pension-plan reserves, but "unusual and exigent circumstances" in banking, commercial-paper, and derivatives markets. It was asserted that "a disorderly failure of AIG could add to already significant levels of financial market fragility and lead to substantially higher borrowing costs, reduced household wealth, and materially weaker economic performance" (9/16/08 Federal Reserve Press Release cited by Sjostrum, p. 977). The irony is that the dire events envisioned were going to happen whether or not AIG's counterparties were forced to take their lumps in a hastily negotiated bankruptcy settlement. Because blanket guarantees typically finance negative-value gambles for resurrection, Kane (2009) argues that keeping zombie institutions like AIG in play without subjecting their asset and funding structures to triage prolongs and intensifies - rather than mitigates - the adverse effects that these firms exert on the real economy.

Figure 1 shows that AIG's stock price fell sharply during the panic, but remained well above zero through the end of 2008. The continued decline in this price and in indices of consumer and business confidence in October and November 2008 support the following hypothesis: that the $\$ 700$ Billion bailout and the lack of checks and balances in the Emergency Economic Stabilization Act combined with poorly explained differences in the extravagance of government assistance across the chain of 2008 bailouts to lead the citizenry to lose faith in the 
competence and economic priorities of the nation's top economic officials. Unlike Santa Claus, the Fed and Treasury seemed determined to give gifts only to firms that had behaved badly.

An authoritative account has yet to emerge of which officials knew what and when they knew it. But as a minimum, state and federal regulators should have noticed that profitability of AIG's financial-services units had been declining for several years at a rate that, thanks to implicit and explicit cross-guarantees, threatened its ability to pay policyholder and pension claims in its traditional and retirement insurance businesses. The breakdown in supervision was not just that state and OTS personnel failed to observe and curb AIG's growing losses and loss exposures, but that the Fed and foreign counterpart agencies turned a blind eye to the nonperformance risk that was building up in banking and securities firms that held the other side of AIG's deals. The depth and breadth of the global regulatory failure suggest that an unspoken reason for reflexively bailing out AIG's creditors and counterparties was bureaucratic blame avoidance. In the US in particular, top officials of a highly unpopular Bush Administration could not reasonably expect to hold office beyond January 20, 2009. The rescue's generous treatment of AIG creditors and counterparties converted what would have been immediate industry criticism for being asleep at the wheel into applause for the Treasury's fast action and political bravery and shifted the unpopular task of explicitly financing the rescue forward onto the Fed and succeeding administrations.

\section{Regulation of Swaps}

Swaps and other contracts whose net worths "derive” from referenced instruments are financial derivatives. I believe that the AIG case shows us that the next round of safety-net arbitrage is likely to be rooted in the difficulty of regulating swaps that, like CDS and CDARS, substitute for traditional insurance and pension coverages. Swaps are financially engineered substitutes for straightforward forms of indirect finance, forms that themselves serve as substitutes for arrangements that offer direct funding from savers to investors. Constructively, a swap agreement is a multiperiod forward contract between two counterparties. In a swap, the parties agree to exchange cash flows from one hypothetical or "notional” instrument at specified settlement dates for the cash flows from a second designated instrument. Either or both of the instruments may-but need not-- have a precise cash-market counterpart. The two sides of each swap may be regarded as establishing a synthetic incremental balance sheet that renders each counterparty long a series of claims (known as the "receive half") and short a series of obligations (the "pay half”). As a balance sheet, the value difference between the two halves is the contract's net worth.

But the statutory definition of the term "swap" embraces a much wider range of deals than this constructive description accommodates. In particular, it authorizes insurance and reinsurance contracts to be written as swaps. The statutory concept of a swap includes, in part, any agreement, contract or transaction "that provides for any purchase, sale, payment or delivery (other than a dividend on an equity security) that is dependent on the occurrence, nonoccurrence, 
or the extent of the occurrence of an event or contingency associated with a potential financial, economic, or commercial consequence.”3

The problem is twofold. First, the staffs of the federal agencies charged with regulating swap markets - the SEC and CFTC—have developed expertise and tools appropriate for supervising individual and enterprise and market conduct rather than systemic risk. Second, industry influence on these agencies has been substantial. Neither agency is likely to elevate taxpayers' interests over those of the industries they regulate and represent. The revolving door between the SEC and the securities industry spins much harder than any of the levers agency personnel use to fight against corporate fraud and misrepresentation. The revolving door has also helped the derivatives industry to win preferential treatment for swaps and repos in bankruptcy that runs roughshod over taxpayers' interests.

It has been left to state insurance regulators, exchanges, dealers, and brokers to assess contract risk and to use bonding tools (e.g., screening traders' net worth; establishing margin requirements; and enforcing minimum standards for collateral quality) to assure counterparty performance. The industry's principal risk-assessment tool is value-at-risk analysis, which specifically excludes the very low-probability events that most apt to trigger systemic problems. Moreover, the MF Global scandal suggests that rules governing the rehypothecation of collateral and position netting may make posted margins less than fully collectable when a major swap participant defaults.

Historically, most swaps have been arranged with a third-party dealer or market-maker. This trader collects a fee for lessening the due-diligence and search costs that its customers might otherwise face. The fee may be expressed as a spread between the terms offered for taking up one side or the other of a particular swap. As compared with a brokered market, the customer receives immediate execution and the dealer becomes the counterparty for both sides of the deal.

Whether an individual is a saver or an investor, the opportunity costs encountered in undertaking a swap parallel those met in comparing the benefits and costs of contracting directly with a household or nonfinancial firm against using (say) a bank to intermediate the deal. Prudent savers and investors have to assess the differences in the benefits of contracting indirectly and weigh these benefits against the differences in transaction costs. Most households, lack the expertise needed to make direct lending or borrowing the better alternative. Efficient deal-making generates two types of transactions costs: pre-contract shopping, negotiating, and due-diligence expense and post-contract enforcement and unwinding expense.

When the two halves are equally valuable, the swap is said to be "at" or "on" the market. Usually, however, the incremental balance sheet of one counterparty will show positive net worth. That party faces a risk that the party with negative net worth will renege on some or all of its obligation. If it were not for this nonperformance risk, one could construct combinations of swap contracts that would reproduce synthetically the exact cash flows generated by any cashmarket portfolio or government-chartered financial intermediary. This means that differences in

\footnotetext{
${ }^{3}$ CEA Section 1a(47)(A)(ii), 7 U.S.C. 1a(47)(A)(ii).
} 
the dangers of nonperformance (known in the trade as “counterparty risk”) lie at the heart of the regulatory problems that swaps and other derivatives pose for society.

Because banking, securities and insurance products have existed for hundreds of years, the dimensions of their regulatory environments have been nailed down in important ways. But because swap contracts are less than a half-century old, their regulatory environment is much more fluid. The volume of interagency rule-making to be completed under the Dodd-Frank Act of 2010 makes the toolkits and architecture of future swaps regulation particularly swampy today.

Data on the size of and potential imbalances in dealer positions are not readily available. But the major dealers were giant banking institutions that benefited from the perception that they would not be allowed to fail. In hopes of pushing swaps trading outside the net, The Dodd-Frank Act asks the Securities and Exchange Commission (SEC) and the Commodities Futures Trading Commission (CFTC) to set rules whose intent is to force high-volume swap instruments to be standardized as far as possible and the trading in such instruments to be forced onto organized exchanges where hypothetically positions might be monitored and supervised more effectively. On an exchange, the search function is undertaken jointly by brokers who transmit customer bids and offers to the exchange and by the exchange which clears the trades and guarantees that execution will occur on the trading date.

Performance guarantees on an exchange are backed up formally by broker and exchange due-diligence, collateral assessment, and margining procedures. At both the exchange and broker levels, margin and net-worth requirements are set relative to the perceived volume and character of a counterparty's trading. Brokers protect themselves by screening customers and margining the value of short sales and pending trades. Exchanges support contract performance further by screening brokers for reputation, competence, and net worth and by holding margin accounts posted by brokers. If a customer or broker fails to deliver its half of the trade on the execution date, the exchange's clearing corporation or partnership is obliged to complete the trade.

But dictating exchange trading for standardized swaps is different from eliminating the possibility of safety-net arbitrage. First, forcing unwilling dealers to shift the bulk of their market-making activity onto an exchange is much easier said than done. Because standardized swaps carry more basis risk than customized ones, many customers will continue to prefer customized terms, all the more so since giant dealer banks will be smart enough to protect their dominant positions by stressing the value of customization and adopting pricing policies that shift a portion of their safety-net subsidy forward. Second, the more important swaps trading on a particular exchange might become, the better its clearing members will see that adopting a corporate form will limit their individual and joint liability in crises and would help them if the exchange itself should ever become insolvent to whip up the financial, political and administrative fear necessary to trigger the bailout reflex. 
9. Need for massive changes in the information flows and relationships linking taxpayers to protected firms.

The current wave of Reregulation is much weaker than it looks. Incentive conflict remains the central problem. To reduce incentive conflict, society must explore ways to identify shadowy arrangements promptly and to regulate their access to the safety net more effectively (cf. Schwarcz, 2012). To my mind, this requires society to find ways to impose and enforce stronger and clearer moral duties on unwilling financiers, politicians, regulators, and creditrating firms (Kane, 2010a and b).

Financial safety nets are needed only because of imperfections in transparency and in the enforceability of rights to deter risk-shifting that individual-country contracting environments convey to institutional creditors and counterparties. To be efficient, the design and operation of a country's safety net must not only respond to country-specific weaknesses in the transparency and deterrency offered by private financial contracts, it must more importantly repair longstanding weaknesses in governmental accountability. Defects in the transparency of and responsibility for safety-net costs are imbedded in the social contract that regulators and the financial sector have imposed on the rest of society. How much any particular change in rules improves the government's contracting environment ought to be the benchmark by which we judge financial reforms. The more shadowy the regulatory environment remains, the more likely it is that governmental guarantees inherent in the rescue reflex will undermine financial stability and misdirect much of a country's scarce savings into wasteful investments. To identify a likely source of future problems, the paper warns that safety-net subsidies generated by swaps that substitute for reinsurance contracts are not now being monitored in timely and effective fashion, and that a failure in this market could create great social unrest by undermining the ability to deliver on promises made in the pension and insurance industries.

I believe society would be better off if it were the newly formed Office of Financial Research (OFR) rather than the Federal Reserve that enjoyed statutory independence. To be free to measure and report on systemic risk, the OFR desperately needs the freedom to resist shortterm political interference. To begin to reclaim an effective role in the political system, taxpayers need to receive regular and unbiased estimates of their side of the taxpayer put. Precisely because the benefits of shadowy arrangements are overpraised by their proponents, unconventional substitute instruments ought to be routinely screened for tail risk and safety-net consequences by the OFR. The OFR ought to be notified to undertake this analysis by any market maker as soon as its own volume of trading in any over-the-counter derivative contract surpasses a specified size threshold. With the help of trade associations for traditional types of financial institutions, the OFR ought also to be on the lookout for fast-growing financial firms, especially those that adopt unconventional funding structures.

Authority to disallow contracts or institutions or adjust deal-making parameters that the OFR finds to be dangerous could be assigned to the Systemic Risk Oversight Council or separately to various federal agencies based on their being able to demonstrate to the OFR the 
capacity to design and enforce a reliable system for monitoring and reserving for the loss exposures at issue.

TABLE 1

SOURCES OF AIG PROFIT AND LOSS, 2005 THROUGH SEPTEMBER 30, 2008

\begin{tabular}{|c|c|c|c|c|}
\hline (in millions) & $\begin{array}{l}\text { Nine Months } \\
\text { Ended } \\
\text { 9/30/08 } \\
\end{array}$ & 2007 & 2006 & 2005 \\
\hline \multicolumn{5}{|l|}{ Revenues } \\
\hline General Insurance & $\$ 35,854$ & $\$ 51,708$ & $\$ 49,206$ & $\$ 45,174$ \\
\hline $\begin{array}{l}\text { Life Insurance \& } \\
\text { Retirement }\end{array}$ & 14,271 & 53,570 & 50,878 & 48,020 \\
\hline Financial Services & $(16,016)$ & $(1,309)$ & 7,777 & 10,677 \\
\hline Asset Management & 658 & 5,625 & 4,543 & 4,582 \\
\hline Other & 531 & 457 & 483 & 344 \\
\hline $\begin{array}{l}\text { Consolidation \& } \\
\text { Eliminations }\end{array}$ & (436) & 13 & 500 & (16) \\
\hline Total & $\$ 34,862$ & $\$ 110,064$ & $\$ 113,387$ & $\$ 108,781$ \\
\hline \multicolumn{5}{|l|}{$\begin{array}{l}\text { Operating Income } \\
\text { (Loss) }\end{array}$} \\
\hline General Insurance & $\$(393)$ & $\$ 10,562$ & $\$ 10,412$ & $\$ 2,315$ \\
\hline $\begin{array}{l}\text { Life Insurance \& } \\
\text { Retirement }\end{array}$ & $(19,561)$ & 8,186 & 10,121 & 8,965 \\
\hline Financial Services & $(22,880)$ & $(9,515)$ & 383 & 4,424 \\
\hline Asset Management & $(2,709)$ & 1,164 & 1,538 & 1,963 \\
\hline Other & $(2,899)$ & $(2,140)$ & $(1,435)$ & $(2,765)$ \\
\hline $\begin{array}{l}\text { Consolidation \& } \\
\text { Eliminations } \\
\end{array}$ & 237 & 722 & 668 & 311 \\
\hline Total & $\$(48,205)$ & $\$ 8,943$ & $\$ 21,687$ & $\$ 15,213$ \\
\hline
\end{tabular}

Source: Sjostrum (2009), p. 947. 


\section{FIGURE 1}

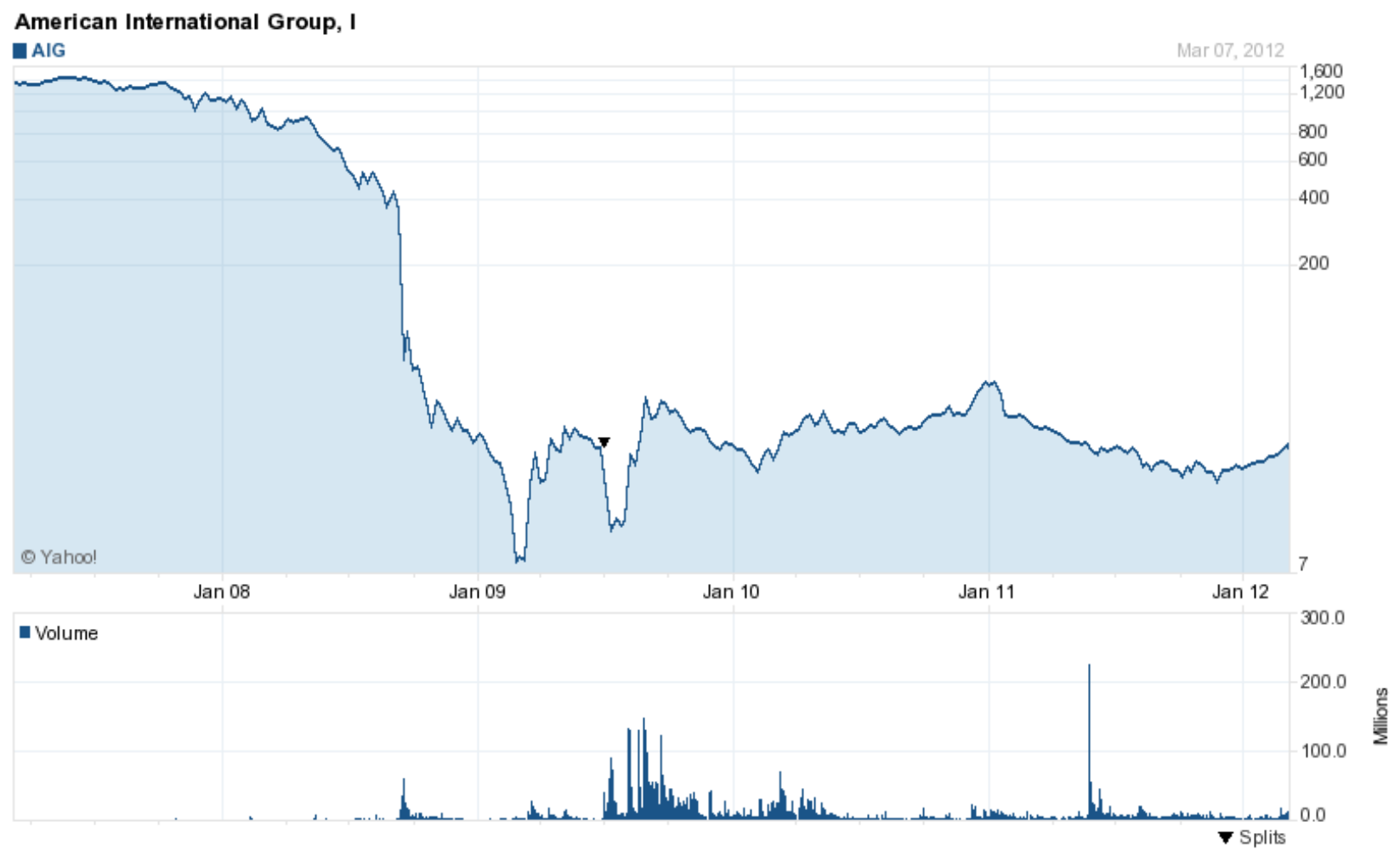




\section{REFERENCES}

Carbo, Santiago, Edward J. Kane, and Francisco Rodriguez, 2008. “Evidence of Differences in the Effectiveness of Safety-Net Management in European Union Countries," Journal of Financial Services Research, 34 (Sept./Dec.), 151-176.

2011a. "Evidence of Regulatory Arbitrage in Cross-Border Mergers of Banks in the EU," Journal of Money, Credit, and Banking_(forthcoming)

,2011b. "Safety-Net Benefits Conferred on Difficult-to-Fail-and-Unwind Banks in the US and EU Before and During the Great Recession," Journal of Banking and Finance (forthcoming).

Carow, Kenneth, Edward J. Kane, and Rajesh Narayanan, 2011. "Safety-Net Losses from Abandoning Glass-Steagall Restrictions," Journal of Money, Credit, and Banking (forthcoming).

Diamond, Douglas W. and Raghuram G. Rajan, 2000. "A Theory of Bank Capital," Journal of Finance, 55 (December), 2431-2465.

Gorton, Gary, 2010. Slapped by the Invisible Hand: The Panic of 2007. New York: Oxford University Press.

Grody, Allan D., 2011. "A Big First Step for Spotting a Systemic Risk," American Banker 177, September 28.

Hawke, John D., Jr., 2012. “Ask Questions Before Shooting Money Market Funds," January 9. (http://www.americanbanker.com/bankthink) , 2012b. "Why Paul Volcker is Wrong About Money Market Funds," February 3. (http://www.americanbanker.com/bankthink) 
Kane, Edward J., 1981. "Accelerating Inflation, Technological Innovation, and the Decreasing Effectiveness of Banking Regulation," Journal of Finance, 36 (May), 355-367. 1983. "Policy Implications of Structural Changes in Financial Markets," American Economic Review (Papers and Proceedings), 73 (May), 96-100. 2006. "Confronting Divergent Interests in Cross-Country Regulatory Arrangements," Reserve Bank of New Zealand Bulletin, 69(June), 5-17. , 2007. "Basel II: A Contracting Perspective," Journal of Financial Services Research, 32 (October), 39-53. 2009. "Incentive Roots of the Securitization Crisis and Its Early Mismanagement," Yale Journal of Regulation, 26 (summer), 405-416.

,2010a. "Importance of Monitoring and Mitigating the Safety-Net Consequences of RegulationInduced Innovation," Review of Social Economy, 58 (June),145-162.

,2010b. “Redefining and Containing Systemic Risk," Atlantic Economic Journal, 38, 251-264. , 2012. "Bankers and Brokers First: Loose Ends in the Theory of Central Bank Policymaking," (unpublished).

Kindleberger, Charles P., 1978. Manias, Panics, and Crashes: A History of Financial Crises, New York, Basic Books (first edition).

Koehn, Michael and Anthony M. Santomero, 1980. "Regulation of Bank Capital and Portfolio Risk," Journal of Finance, 35 (December), 1235-1244.

McCulley, Paul, 2007. Teton Reflections: PIMCO Global Central Bank focus PIMCO (Sept.), http://www.pimco.com/EN/Insights/Pages/GCBF\%20August-\%20September\%202007.aspx. 
Randall, Susan, 1999. "Insurance Regulation in the United States: Regulatory Federalism and the National Association of Insurance Commissioners," Florida State University Law Review, 26, 625699.

Reinhart, Carmen M., and Kenneth S. Rogoff, 2009. This Time is Different: Eight Centuries of Financial Folly. Princeton: Princeton University Press.

Schwarz, Steven L., 2012. "Regulating Shadow Banking.” Boston University Review of Banking \& Financial Law (forthcoming).

Sjostrum, William K., Jr., 2009. “The AIG Bailout," Washington \& Lee Law Review, 66, 943-991.

Wilson, James Q., 1980. The Politics of Regulation. New York: Basic Books. 